\title{
The Quantitative Analysis of Research Papers on Library's Human Resource Management from 2007 to 2016 in China
}

\author{
Yue Dong ${ }^{1, a}$ and Lei Wang ${ }^{2, b^{*}}$ \\ ${ }^{1}$ Beihua University library, 3999 East Binjiang Road, Fengman District, Jilin, Jilin, China \\ ${ }^{2}$ Personnel office, Beihua University, 3999 East Binjiang Road, Fengman District, Jilin, Jilin, China \\ a346034656@qq.com, b513636202@qq.com \\ * Corresponding author
}

Keyword: Library; Human resource mananement; Bibliometrics; Statistical analysis

\begin{abstract}
Taking the CNKI database as the source origin, this paper analyses the research papers on hu-man resource management of the library in China from 2007 to 2016. A quantitative analysis is made from the Publication time, journals, authors, author's units, keywords and paper topics. The study summarizes the status of China's humam resource management of the library and put forward some suggestions.
\end{abstract}

\section{Data Sources and Research Methodology}

Data Sources. Select the CNKI Chinese Journal Full-text Database as data sources, the use of very high retrieval methods, with "key words" as the search term, "library" and "human resources management" as the key words, the time span from 2001 to 2010, the retrieval time for September 10, 2011. In order to ensure the recall, journal scope for all journals, for to improve the precisionAnd choose "exact match". A total of 1691 articles retrieved, not from primary and non related documents and documents before January 1, 2001 a total of 96, the actual statistics of 1595 papers.

Research Methods. By using bibliometric analysis and content analysis, statistics and Analysis on 1595 papers retrieved, to study the selected papers of the year, authors, institutions, journals, keywords, abstract and so on.

\section{Author Statistics and Analysis}

Author Delivery Quantity Analysis. A total of 1595 papers by 1753, of which 1384 people, first author, co-author of 369 papers, which are shown in Table 1. Table 1 shows the authors research on the human resource management of the library of CKNI China Journal Full-text Database, $90.41 \%$ authors only published 1 articles There are only 10 writers who have published more than 4 papers. (8) : Huang Rong, issued 6: Chen Huiqian, issued 5: Xu Jianhua), accounting for only $0.58 \%$ of the total number of authors; The author of 3 papers, 16 people, if there are 3 or more posts as the core author, there are 26 people, The author only accounted for $1.49 \%$ of the total, and 26 people in a cooperative effort by 12 , accounting for $46.15 \%$ of the core authors, core authors published number 95 , working papers 19 , accounted for $20 \%$. of the total number of core authors in 1595 papers retrieved in cooperation papers 302, accounted for the Total $18.9 \%$.

Table 1 Statistics of papers published by the authors

\begin{tabular}{|c|c|c|c|c|c|c|c|}
\hline Dispatch / article & 8 & 6 & 5 & 4 & 3 & 2 & 1 \\
\hline Author / person & 1 & 1 & 4 & 7 & 16 & 142 & 1585 \\
\hline Percentage /\% & 0.06 & 0.06 & 0.06 & 0.40 & 0.91 & 8.10 & 90.41 \\
\hline
\end{tabular}

From the above analysis results, at present our country research on human resource management of the library and author of more, dispatch number is large, and the prolific author of the quantity is less, the number of cooperation is low, the proportion of extremely low, indicating that in the library industry and 
experts in the number of core authors on research in the field of human resource management of the library very limited, basically did not form the core backbone of the team, did not form a team, the number of research. Although there are many, but most of the authors only general discussion, research achievements, no system has just started, and terminates, no study of continuity and depth of the system.

The Institution Under Which the Author Belongs. The author of this thesis belongs to many types of institutions, both public library, University Library, library of secondary vocational school, specialized library, there are universities and research institutes, and enterprises, hospitals and other organizations. In this paper, which is divided into five categories, namely: university libraries, public libraries, colleges and universities, The number of authors and publications in the institutions of higher learning and other institutions is different from each other. See table 2. As can be seen from table 2, authors of different types of in stitutions And a significant differences.

Table 2 Statistics of the numbers of papers published by in stitations and first authors

\begin{tabular}{|c|c|c|c|c|c|}
\hline Type of institution & $\begin{array}{c}\text { Number of } \\
\text { institutions }\end{array}$ & $\begin{array}{c}\text { First author } \\
\text { number }\end{array}$ & $\begin{array}{c}\text { The total ratio } \\
\text { of the author: }\end{array}$ & $\begin{array}{c}\text { Number of } \\
\text { publications / } \\
\text { articles }\end{array}$ & $\begin{array}{c}\text { The total } \\
\text { accounted for } \\
\text { ratio /\% }\end{array}$ \\
\hline College ibrary & 530 & 796 & 57.5 & 984 & 61.7 \\
\hline $\begin{array}{c}\text { public library } \\
\text { Colleges and departments }\end{array}$ & 293 & 364 & 26.3 & 121 & 7.6 \\
\hline $\begin{array}{l}\text { Institute of scientific } \\
\text { research information }\end{array}$ & 42 & 53 & 3.8 & 55 & 3.4 \\
\hline Other mposite & 51 & 57 & 4.1 & 60 & 3.8 \\
\hline Total & 1017 & 1384 & 100 & 1595 & 100 \\
\hline
\end{tabular}

The universities and colleges library, the author and the number has obvious advantages, the author of the first author of the total $83.8 \%$, the total number of published papers published in $85.2 \%$, the public library is relatively small, research institutes and other comprehensive institutional researchers is less, this that colleges and Universities Library is the main force of library human resource management at the same time.Also, from the other side reflects China's study on human resource management of the library and is still not enough, especially in the situation when the public information, knowledge of Public Library as the socialization of the human resource management is more important, the research is not enough. Analyze the reasons, I think that the main: a considerable number is The university has management and resource science and technology disciplines, disciplines under the human resources and human resources management two disciplines, disciplines related to professional personnel, human resources of the library is its research category, its author and natural number is dominant; two is the subject for relying on the college library originally, there are a large number of librarians are the main members of the discipline of professional talents, the library in order to better serve the discipline construction, a special subject librarian, the librarian will naturally pay more attention and study Three, the public library; without relying on professional knowledge, the focus of the work and the service object is different from the requirements of university library, libraries and research institutes, librarians and curators have focused on the different.Researchers in the field will naturally be less.

\section{Statistics and Analysis of Published Periodicals}

In the past 10 years, in the CNKI Chinese journals full-text database contains papers on library human resources management research in 437 different journals, in order to facilitate statistical analysis, this paper will be published in 437 journals two times respectively statistics, one is that all journals are divided into three categories, namely professional class, LIS University Journal, comprehensive academic journal of statistics, two will be published 5 papers and periodicals, accounting for more than the amount of related document than a statistical. The LIS journals published the most common species are the least, 67, accounted for $15.3 \%$ of the total journals, published 998 papers, accounting for $62.6 \%$ of the total issued, University Journal 209, accounting for $47.7 \%$ of the total journals, published 285 papers, accounting for the total number of $17.8 \%$, other comprehensive academic journals 162, accounting for the 
total journals the $37 \%$, published 312 papers, accounting for $17.8 \%$ of the total issued, the number more than 5 articles in 59 journals, LIS 48, accounting for the total 5 articles published in journals and more than $81.1 \%$ universities, only 1 , accounting for $1.7 \%$. of the total journals visible on the human resource management of the library the distribution is extremely uneven, mainly concentrated in the distribution of LIS journals, many journals are concerned about the results of this study, this is undoubtedly worthy of Libraries Pleased. Similarly, although LIS journals more emphasis on human resources research library, and most of them is an important information source of human resource management of the library, its importance is different, and the library science journals "Chinese Library Journal" and the National Library of "sponsored by the National Library of China" published in recent 10 years the library human resources management research papers only 5, 6, which also shows the importance of the research, perhaps because of such outstanding research fruit in too little. In short, the results of human resource management research of Library Science Research in the proportion is not high in the whole book information, nearly 10 years most professional journals have published some papers and publications, also very impressive, they have become the main research on human resource management of the library Academic exchanges should be made.

\section{Keyword Statistics and Analysis}

Through the statistical analysis of the key trends, researchers can clearly understand the content, the attention of researchers and research hot spot. In the process of statistical analysis, this article mainly is carries on the statistics and Analysis on the author searched 1595 papers in our own key is given.

In the 1595 paper, the author provides a total of keywords 4830, will remove duplicate and merge synonymous there after 895, high frequency "human resources management" and "library" were 657 times and 623 times, the frequency is below 10 times841, there are more frequent 1 times, 597, accounting for $66.6 \%$. of the total number of keywords, because the author gives too many keywords, this article only provides frequency appeared in more than 5 times (including 5 times) 97 keywords and frequency table.

The table 3 shows the high frequency keywords, the highest frequency is "human resources management", the second is the "library" two key frequency are more than 630 times, "human resources, University Library" frequency is also nearly 300 times, but from the above 4 a high frequency words Look, can not explain the domestic library human resource management research and focus on the hot issues, from the statistical frequency of occurrence in more than 5 keywords, you can get a glimpse of the library knowledge management, the research of human resources management innovation, measures and mechanism, the management, performance appraisal, human resource development is a hot issue however, management theory, management mode, occupation career, occupation qualification, talent team construction, the quality of the librarians are the main content of research in recent years. 
Table 3 The key words marked by the authors and their frequency of occurrence

\begin{tabular}{|c|c|c|c|c|c|c|c|}
\hline Key word & $\begin{array}{c}\text { frequenc } \\
\mathrm{y}\end{array}$ & Key word & $\begin{array}{c}\text { frequen } \\
\text { cy }\end{array}$ & Key word & $\begin{array}{c}\text { freque } \\
\text { ncy }\end{array}$ & $\begin{array}{c}\text { Key } \\
\text { word }\end{array}$ & $\begin{array}{c}\text { freque } \\
\text { ncy }\end{array}$ \\
\hline $\begin{array}{l}\text { Human resource } \\
\text { management }\end{array}$ & 669 & $\begin{array}{c}\text { Develop } \\
\text { ment }\end{array}$ & 13 & $\begin{array}{c}\text { Core } \\
\text { competenc } \\
\mathrm{e}\end{array}$ & 8 & Library & 635 \\
\hline $\begin{array}{c}\text { Professional } \\
\text { qualification } \\
\text { certification system }\end{array}$ & 12 & $\begin{array}{l}\text { managem } \\
\text { ent theory }\end{array}$ & 8 & $\begin{array}{l}\text { Human } \\
\text { resources }\end{array}$ & 380 & $\begin{array}{l}\text { human } \\
\text { capital }\end{array}$ & 12 \\
\hline service & 8 & $\begin{array}{l}\text { College } \\
\text { Library }\end{array}$ & 288 & $\begin{array}{c}\text { Managem } \\
\text { ent } \\
\text { mechanis } \\
\text { m }\end{array}$ & 12 & $\begin{array}{l}\text { knowled } \\
\text { ge capital }\end{array}$ & 7 \\
\hline knowledge management & 160 & reform & 12 & problem & 7 & $\begin{array}{c}\text { Library } \\
\text { managem } \\
\text { ent } \\
\end{array}$ & 152 \\
\hline personnel management & 11 & $\begin{array}{l}\text { Situation } \\
\text { managem } \\
\text { ent }\end{array}$ & 7 & Librarian & 86 & $\begin{array}{l}\text { Human } \\
\text { resources } \\
\text { construct } \\
\text { ion }\end{array}$ & 11 \\
\hline Work study program & 7 & $\begin{array}{l}\text { knowledg } \\
\text { e } \\
\text { economy }\end{array}$ & 83 & $\begin{array}{c}\text { mechanis } \\
\mathrm{m}\end{array}$ & 11 & $\begin{array}{l}\text { Knowled } \\
\text { ge } \\
\text { Librarian }\end{array}$ & 6 \\
\hline innovate & 74 & $\begin{array}{c}\text { Librarian } \\
\text { Quality }\end{array}$ & 11 & $\begin{array}{c}\text { Optimal } \\
\text { allocation }\end{array}$ & 6 & $\begin{array}{c}\text { Counter } \\
\text { measures }\end{array}$ & 69 \\
\hline Career management & 10 & $\begin{array}{c}\text { Tacit } \\
\text { knowledg } \\
\mathrm{e}\end{array}$ & 6 & $\begin{array}{c}\text { excitation } \\
\text { mechanis } \\
\text { m }\end{array}$ & 65 & $\begin{array}{l}\text { knowled } \\
\text { ge } \\
\text { service } \\
\end{array}$ & 10 \\
\hline Research & 6 & $\begin{array}{l}\text { Administr } \\
\text { ation }\end{array}$ & 48 & $\begin{array}{l}\text { Present } \\
\text { situation }\end{array}$ & 10 & $\begin{array}{l}\text { informati } \\
\text { on } \\
\text { resources } \\
\text { managem } \\
\text { ent } \\
\end{array}$ & 6 \\
\hline
\end{tabular}

Keywords is the theme refining, summary of the retrieved 1595 papers given by the author of all keywords, although the authors provide keywords very scattered, some even is not accurate, But it can be seen that the subject of its research is very extensive, involving all aspects of human resources and management There are both macro strategic concepts, such as mechanism, knowledge management, humanistic management, and ability based management

The contents of innovation, humanistic care, and also in view of theoretical level content, such as the management of library human resources planning, target value, etc. the function principle and content, practice content Such as the study, post allocation, librarian recruitment, training and development, the use of pay and benefits, performance evaluation, employee motivation, labor relations, occupation career planning, occupation qualification and other specific content and links. The results of these studies to better adapt to modern human resource management of the library in the era of knowledge economy and information requirements for the field the research provides important theoretical and practical basis. But from the entire table keywords appear frequency is also visible the research topics scattered, systematic and theoretical depth is not enough.

\section{Summary}

In the past 10 years, the domestic library human resources management research achievements. Research papers both in quantity and quality has shown a good trend; the author is a librarian mostly, but also many experts and scholars; LIS journals has become the main position of the exchange of research results, provides great convenience for librarians to carry out academic exchanges; research keep pace with the 
times, combined with the new form of Library Development Research Such as, digital library, compound library and other new museum of human resources to conduct special studies, the researchers make use of their own knowledge advantage, the introduction of domestic and foreign human resources management concepts and methods, to promote the theory and practice of human resource management of domestic library development, accelerate the development of the library better.

However, because human resource is the most important resource in organizations, regardless of any time, any situation all cannot do without the human resources of this important resource, at the same time, the content of human resource management is very extensive, research in different lead in domestic research on human resource management in many different the best place. Therefore, the human resource management of the library in the future research must also pay attention to the following aspects: the library human resource management and development is the lifeline for the survival and development, we must continue to study the development and management of human resource and attention library, to further enhance the quantity and quality of the research; the development of the research the backbone, expansion of the research team, formed with the authority and the core power of research personnel; the LIS major period Continue to pay attention to the issue of research results, look forward to more professional core journals and authoritative publications pay more attention to their research results; strengthen the cooperation study, the formation of the study field of core team; from the theory to strengthen the systematic and in-depth, and gradually improve the theoretical system, formed with the characteristics of the times to adapt to the needs of library structure theory the development of the local human resources management system, establish a scientific and complete implementation of the standards and methods in the system needs to be applied research. It can be expected, with the people of knowledge and information needs are strong, access to knowledge and information changing way, people expect to change to the library service, higher demands for the human resources and management, has become increasingly important in the research, I believe the majority of experts and scholars and the library's attention and efforts to map Library human resources management will be more scientific and perfect, and library human resources will meet the requirements of the times more, and better promote the healthy and rapid development of the cause of the library

\section{Acknowledgements}

The Department of education of Jilin province "in 13th Five-Year" planning project, "bibliometric analysis of human resource management information (No. GH16054) research"

\section{Reference}

[1] G.Q.Liu:Human resources management of Library [M]. Hefei: Anhui University press, 2016:51-98.

[2] J.Q.Zhong:On the library human resources management new concept J. Journal of information, 2015 (10):126-127.):

[3] .P.Qiu:Information metrology [M]. Wuhan: Wuhan University press, 2016:, 36 - 65.

[4] H.T.Ma:The core of library knowledge management human resource management [J]. Library theory and practice, 2016 (1): 12 - 13.

[5] G.X.Sun,L.Zhang:2006. Bibliometric analysis of research papers on Cataloguing in China [J]. Library theory and practice, 2014 (3): 24 - 27

[6] Y.Q.Xiang, L.Liu:Analysis of the hotspots of information science based on word frequency analysis [J]. Library science research, 2014 (7): 9 - 13.

[7] X.Zhang:Comparative analysis of the present situation of human resources in Chinese and foreign libraries [J]. Science and technology information development and economics, 2016 (9): 15 - 16.

[8] P.Y.Lei:Domestic human resource management of the library of J. Intelligence research, 2015 
(12): 111-113.

[9] M.Z.Xiao:human resource allocation and its role and model [J], journal of China university of geosciences, 2016, (4) : 24-29

[10]E.M.XU, J.M.SUN:human resource development and management Beijing [M] : Beijing: renmin university of China press, 2015.

[11]L.Q.Wei, Z.M.Liu: empirical research on the development of strategic human resource management in Chinese enterprises [J], scientific research, 2015, (12) : 816-819 